\title{
Scrotal abscess as the first symptom of fatal necrotizing pancreatitis
}

Nikica Sutalo, MD, PhD, Vedran Dragisic, MD, Josip Miskovic, MD, PhD, Martina Soljic, MD, PhD.

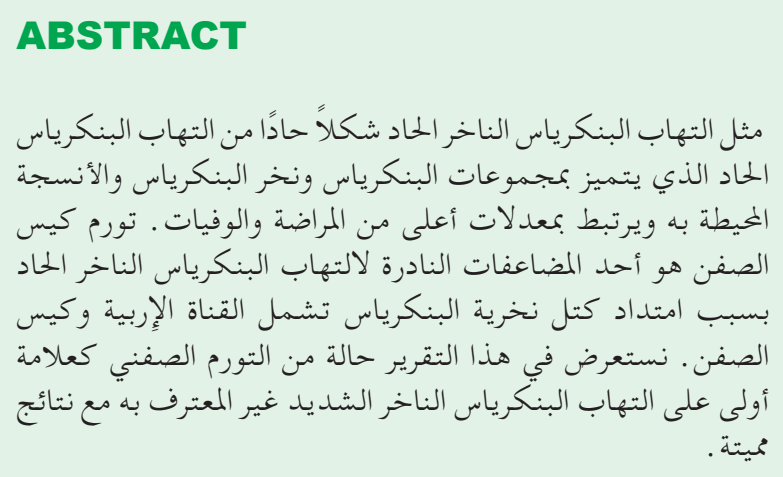

Acute necrotizing pancreatitis represents a severe form of acute pancreatitis, characterized by pancreatic collections and necrosis of the pancreas and surrounding tissues. It is associated with higher rates of morbidity and mortality. Scrotal swelling is a rare complication of acute necrotizing pancreatitis due to the extension of pancreatic necrotic masses involving the inguinal canal and scrotum. We report a case of scrotal swelling as the first sign of unrecognized severe necrotizing pancreatitis with a fatal outcome.

Saudi Med J 2019; Vol. 40 (11): 1167-1170 doi: 10.15537/smj.2019.11.24488

From the Department of Surgery, University Clinical Hospital Mostar, Mostar, Bosnia \& Herzegovina.

Received 25th April 2019. Accepted 21st July 2019.

Address correspondence and reprint request to: Dr. Martina Soljic, Assistant Professor, Department of Surgery, University Clinical Hospital Mostar, Mostar,Bosnia and Herzegovina.E-mail: msoljic@gmail.com ORCID ID: https://orcid.org/0000-0002-1710-1807

A cute pancreatitis is an inflammation of pancreatic tissue, sometimes extending into the surrounding tissue, due to the release of activated pancreatic enzymes. The main causes of this disease are biliary tract disorders and chronic alcoholism. Another notable cause is hyperlipidemia, which is alleged to account for up to $10 \%$ of all pancreatitis episodes. Underlying pathophysiological concepts include hydrolysis of triglycerides by pancreatic lipase and excessive formation of free fatty acids resulting in inflammatory changes and capillary injury. Hyperviscosity and ischemia may also play a decisive role. ${ }^{1}$ Acute pancreatitis can be mild, moderately severe, or severe, based on clinical presentation together with laboratory and radiology findings. Acute pancreatitis is divided into the early phase and the late phase, based on the progression of pathophysiologic changes. The early phase occurs in the first week after the onset of symptoms, with the disease manifesting as a systematic inflammatory response. The late phase, which starts in the second week after the onset of symptoms, can last from weeks to months. It occurs only in patients with moderately severe or severe pancreatitis, and it is defined by persistent organ failure and local complications. Acute pancreatitis is categorized as intestinal edematous pancreatitis (IEP) or necrotizing pancreatitis, according to imaging findings. ${ }^{2}$ Local and systemic complications make treatment of acute necrotizing pancreatitis difficult and challenging. One of the most severe complications of acute necrotizing pancreatitis is the formation of a peripancreatic collection rich in digestive enzymes, which leads to necrosis of peripancreatic tissue and spreading of necrotic collections along the retroperitoneum. The descent of necrotic retroperitoneal collections along the retroperitoneal space to the scrotum is an unusual but possible manifestation of acute necrotizing pancreatitis and can lead to misdiagnosis. Scrotal swelling has been described in published papers as a symptom of IEP and is usually characterized by sterile fluid effusion in the scrotum. ${ }^{3}$

Case Report. Patient information. A 45-year-old man presented to our emergency department with a 3-day history of scrotal swelling and pain in the lower abdomen. Previous medical history revealed epigastric pain and self-medication with pantoprazole and 
ibuprofen without consulting a physician, which had lasted for 14 days before his admission to the hospital. $\mathrm{He}$ was a heavy smoker (up to 40 cigarettes a day) with a history of alcohol abuse. There was no history of testicular or abdominal trauma or of any similar symptoms. A cholecystectomy had been performed 2 years ago in another hospital (Table 1).

Clinical information. The patient was obese (body mass index 37.1) and had an elevated blood sugar level $(16.5 \mathrm{mmol} / \mathrm{L})$, with a resting heart rate of $90 / \mathrm{min}$ and elevated blood pressure of 170/105 mm Hg. Clinical examination revealed a right scrotal swelling associated with red skin discoloration and edema of the scrotum and the right femoral and inguinal region, as well as an impalpable right testicle. There were no visible wounds or skin damage on the scrotum, femoral, or inguinal region. The body temperature was $39.1^{\circ} \mathrm{C}$ (Table 1 ).

Diagnostic assessment. The laboratory findings were as follows: white blood cell count $25 \times 10^{9} / \mathrm{L}$, C-reactive protein (CRP) $390 \mathrm{mg} / \mathrm{L}$, blood urea nitrogen $15.8 \mathrm{mmol} / \mathrm{L}$, creatinine $450 \mu \mathrm{mol} / \mathrm{L}$, and total bilirubin $120 \mu \mathrm{mol} / \mathrm{L}$. Other laboratory findings, including serum and urine amylases, were within normal range. A scrotal ultrasound showed swelling of the scrotal wall and a heterogeneous effusion of the right scrotum that could be followed to the inguinal canal. The right testis was normal in size and morphology, well vascularized. As a scrotal abscess was suspected an urologist was consulted (Table 1).

Therapeutic interventions. The patient was admitted to the department of urology; and emergency surgery was performed. During surgery, $150 \mathrm{ml}$ of fluid was found in the right scrotum. Yellowish pus-like fluid was evacuated, and samples were sent to microbiological analysis. The analysis later revealed infection with the following organisms: Citrobacter spp., sensitive to amikacin, ciprofloxacin, imipenem, and meropenem; Klebsiella pneumoniae, sensitive to ciprofloxacin, imipenem, and meropenem; and Proteus mirabilis, sensitive to amikacin, ciprofloxacin, imipenem, and meropenem. Surgery was completed with incisions of the right scrotum and drainage with partial resection of the tunica albuginea due to the necrosis. Postoperatively, the patient was treated conservatively with antibiotics and nonsteroidal anti-inflammatory drugs (NSAIDs) with regular incision wound dressing (Table 1).

Disclosure. Authors have no conflict of interests, and the work was not supported or funded by any drug company.
The general condition of the patient worsened. There was a persistent discharge of secretion from the wound. Abdominal CT with venous administration of contrast showed the severe form of acute necrotizing pancreatitis, with necrosis of pancreatic parenchyma and necrosis of the peripancreatic tissues (Figure 1). It also showed multiple fluid collections in the retroperitoneal space and abdominal cavity, descending to the inguinal canal and scrotum (Figures $2 \& 3$ ).

After diagnosing acute necrotizing pancreatitis, a surgeon was consulted, and another emergency surgery was performed. A midline laparotomy was performed with pancreatic necrectomy and drainage of the retroperitoneal space and abdominal cavity. Samples of retroperitoneal fluid taken for microbiological analysis showed the same bacteria as in the liquid from the right scrotum: strains of Citrobacter spp. sensitive to amikacin, ciprofloxacin, imipenem and meropenem; Klebsiella pneumoniae sensitive to ciprofloxacin, imipenem and meropenem; and Proteus mirabilis sensitive to amikacin, ciprofloxacin, imipenem and meropenem. Antibiotic therapy was administered and adjusted according to the microbiological findings.

Follow-up and outcome. The patient was admitted to ICU immediately after surgery, and through the next few days, his general condition deteriorated due to sepsis. On day 4 after the operation, the patient died of multiple organ dysfunction, diagnosed according to the Multiple Organ Dysfunction Score (MODS) criteria.

The last clinical parameters taken on the day of death were as follows: ratio of arterial oxygen partial pressure to fractional inspired oxygen $\left(\mathrm{PaO}_{2} /\right.$ $\left.\mathrm{FiO}_{2}\right) 110 \mathrm{~mm} \mathrm{Hg}$, serum creatinine $500 \mu \mathrm{mol} / \mathrm{L}$, serum bilirubin $160 \mu \mathrm{mol} / \mathrm{L}$, pressure-adjusted heart rate (PAR) 25.4, platelet count $38 \times 10^{9} / \mathrm{L}$, Glasgow coma scale (GCS) 2T (intubated). No pathological examination was carried out because the family of the patient did not give consent.

Discussion. Acute necrotizing pancreatitis is characterized by the activation of digestive enzymes resulting in pancreatic glandular necrosis and systemic inflammatory response due to the release of various inflammatory mediators. In cases of acute necrotizing pancreatitis involving the scrotum, liquid retroperitoneal collections descend to the scrotum along the retroperitoneal space. This leads to edema of the scrotum and corresponding inguinal region, the so-called pancreatic hydrocele. ${ }^{4}$ With treatment and regression of pancreatic inflammation, most cases of pancreatic hydrocele resolve spontaneously, without the need for surgical intervention. A rare manifestation of 
Table 1 - Timeline representation of the case report.

\begin{tabular}{|c|c|c|c|}
\hline Date & $\begin{array}{l}\text { Summaries from initial and follow-up } \\
\text { visits }\end{array}$ & Diagnostic testing & Interventions \\
\hline $\begin{array}{l}\text { Relevant } \\
\text { past medical } \\
\text { history and } \\
\text { interventions }\end{array}$ & \multicolumn{3}{|c|}{$\begin{array}{l}\text { Previous medical history revealed epigastric pain and self-medication with pantoprazole and NSAIDs without consulting a physician, } \\
\text { lasting for } 14 \text { days before admittance. Cholecystectomy was performed } 2 \text { years ago in another hospital }\end{array}$} \\
\hline Day zero & $\begin{array}{l}\text { Three-day history of scrotal swelling } \\
\text { and pain in the lower abdomen } \\
\text { BP } 170 / 105 \mathrm{~mm} \mathrm{Hg} \\
\text { HR } 90 / \mathrm{min} \\
\text { Body temperature } 39.1^{\circ} \mathrm{C} \text { on } \\
\text { admission to hospital }\end{array}$ & $\begin{array}{l}\text { Laboratory findings: BGL } 16.5 \mathrm{mmol} / \mathrm{L}, \mathrm{WBC} 25 \times 10^{9} / \mathrm{L} \text {, } \\
\mathrm{CRP} 390 \mathrm{mg} / \mathrm{L}, \mathrm{BUN} 15,8 \mathrm{mmol} / \mathrm{L}, \mathrm{creatinine} \\
450 \mu \mathrm{mol} / \mathrm{L} \text {, and total bilirubin } 120 \mu \mathrm{mol} / \mathrm{L} \\
\text { Scrotal ultrasound: swelling of the scrotal wall and } \\
\text { heterogeneous effusion of the right scrotum that can be } \\
\text { followed to the inguinal canal } \\
\text { Right testis normal in size and morphology, well } \\
\text { vascularized }\end{array}$ & $\begin{array}{l}\text { Urologist consulted; } \\
\text { incisions of the right } \\
\text { scrotum and drainage } \\
\text { with partial resection of } \\
\text { tunica albuginea due to the } \\
\text { necrosis }\end{array}$ \\
\hline Day 1 & \multicolumn{2}{|l|}{$\begin{array}{l}\text { Admitted to ICU postoperatively } \\
\text { BP } 150 / 90 \mathrm{~mm} \mathrm{Hg} \\
\text { HR } 85 / \mathrm{min} \\
\text { Body temperature } 37.5^{\circ} \mathrm{C} \\
\text { postoperatively }\end{array}$} & $\begin{array}{l}\text { Treated conservatively } \\
\text { with IV fluids, antibiotics } \\
\text { and NSAIDs, with regular } \\
\text { incision wound dressing }\end{array}$ \\
\hline Day 2 & $\begin{array}{l}\text { General condition of the patient } \\
\text { deteriorating with persistent wound } \\
\text { secretion } \\
\text { BP } 170 / 115 \mathrm{~mm} \mathrm{Hg} \\
\text { HR } 100 / \mathrm{min} \\
\text { Body temperature } 38.0^{\circ} \mathrm{C} \\
\text { BP } 100 / 60 \mathrm{~mm} \mathrm{Hg} \\
\text { HR } 75 / \mathrm{min} \\
\text { Body temperature } 37.5^{\circ} \mathrm{C} \\
\text { postoperatively }\end{array}$ & $\begin{array}{l}\text { Abdominal CT with venous administration of contrast: } \\
\text { severe form of acute necrotizing pancreatitis with necrosis } \\
\text { of pancreatic parenchyma and necrosis of the peripancreatic } \\
\text { tissues multiple fluid collections in retroperitoneal space } \\
\text { and abdominal cavity descending to the inguinal canal and } \\
\text { scrotum }\end{array}$ & $\begin{array}{l}\text { General surgeon consulted; } \\
\text { midline laparotomy } \\
\text { performed with pancreatic } \\
\text { necrectomy and drainage } \\
\text { of retroperitoneal space and } \\
\text { abdominal cavity }\end{array}$ \\
\hline Day 3 & $\begin{array}{l}\text { Admitted to ICU postoperatively } \\
\text { BP } 90 / 40 \mathrm{~mm} \mathrm{Hg} \\
\text { HR } 150 / \mathrm{min} \text { with vasopressors } \\
\text { and inotropes } \\
\text { Body temperature } 38.5^{\circ} \mathrm{C}\end{array}$ & $\begin{array}{l}\text { General condition deteriorating because of sepsis and multi- } \\
\text { organ dysfunction } \\
\text { Laboratory findings indicate elevated BUN and creatinine } \\
\text { levels as well as elevated liver enzymes }\end{array}$ & $\begin{array}{l}\text { Treated conservatively } \\
\text { with IV fluids, antibiotics } \\
\text { and NSAIDs with regular } \\
\text { wound dressing } \\
\text { Forced diuresis }\end{array}$ \\
\hline Day 4 & \multicolumn{3}{|c|}{$\begin{array}{l}\text { Patient died due to multiple organ dysfunction caused by sepsis } \\
\text { Last clinical parameters taken on day of death: ratio of arterial oxygen partial pressure to fractional inspired oxygen }\left(\mathrm{PaO}_{2} / \mathrm{FiO}_{2}\right) \\
110 \mathrm{~mm} \mathrm{Hg} \text {, serum creatinine } 500 \mu \mathrm{mol} / \mathrm{L} \text {, serum bilirubin } 160 \mu \mathrm{mol} / \mathrm{L} \text {, pressure adjusted heart rate (PAR) } 25.4, \text { platelet count } \\
38 \times 10^{9} / \mathrm{L} \text {, Glasgow coma scale (GCS) } 2 \mathrm{~T} \text { (intubated) } \\
\text { Pathological examination not carried out because the family of the patient did not provide consent }\end{array}$} \\
\hline & \multicolumn{3}{|c|}{$\begin{array}{c}\text { BP - blood pressure, HR - heart rate, BGL - blood glucose level, WBC - white blood cell count, CRP - C-reactive protein, } \\
\text { BUN - blood urea nitrogen, ICU - intensive care unit, NSAID - nonsteroidal anti-inflammatory drug, } \\
\text { CT - computed tomography }\end{array}$} \\
\hline
\end{tabular}

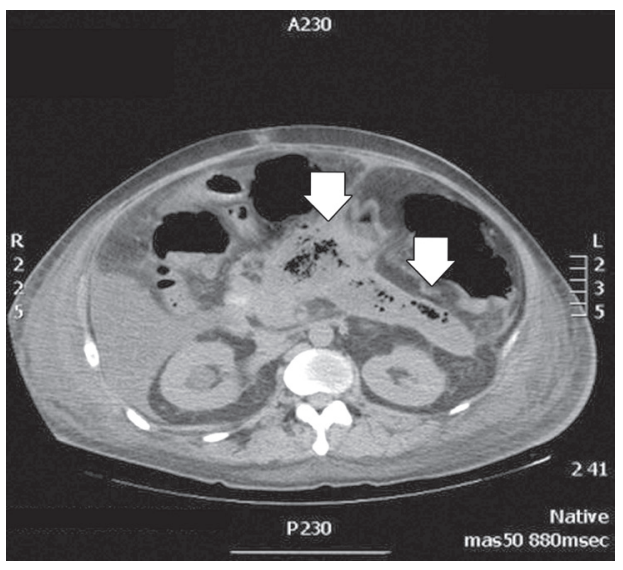

Figure 1 - Computed tomography showing the intravenous application of contrast. Necrotic pancreatic tissue indicated by arrows (axial view).

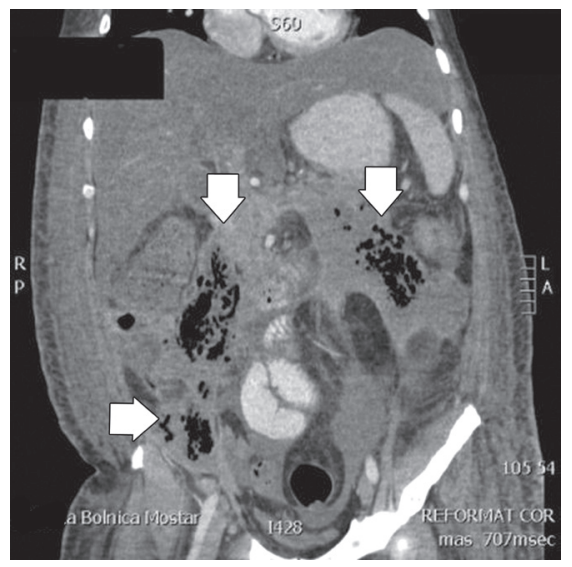

Figure 2 - Computed tomography with intravenous application of contrast. Gas collection in necrotic peripancreatic tissue and descending along the retroperitoneum as indicated by arrows (coronal view). 


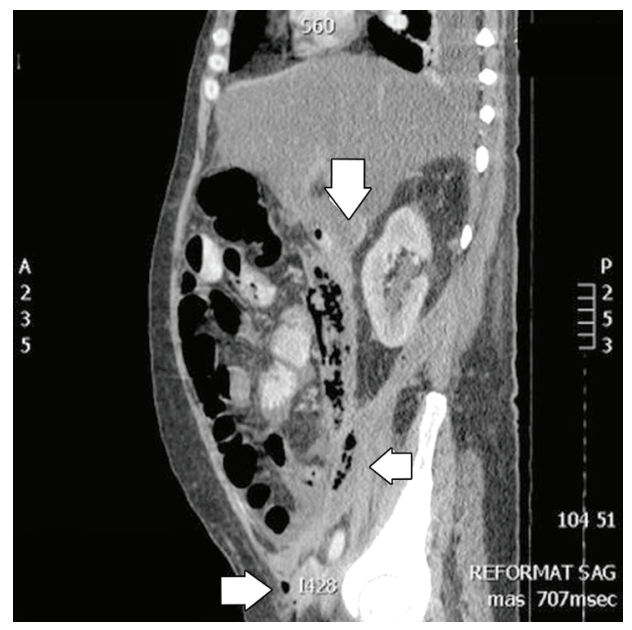

Figure 3 - Computed tomography showing intravenous application of contrast. Gas collection in necrotic peripancreatic tissue, descending to scrotum as indicated by arrows (sagittal view).

pancreatic hydrocele is the formation of a scrotal abscess and scrotal digestion due to pancreatic enzymes.

The patient presented in this paper was admitted with acute scrotal symptoms with unclear etiology. There were no clinical or laboratory findings that suggested acute pancreatitis. The lower abdominal pain was thought to be a symptom of scrotal inflammation and regressed almost completely on admittance. All this contributed to the late diagnosis of acute necrotizing pancreatitis.

The microbiological findings of scrotal and retroperitoneal fluid suggest bacterial transfer from necrotic masses of pancreatic and peripancreatic tissue through the retroperitoneum to the scrotum. We found four cases in the literature describing scrotal swelling as a result of acute necrotizing pancreatitis. ${ }^{5}$

The possibility of compensatory anti-inflammatory response syndrome (CARS) in late-stage acute pancreatitis as the cause of infectious complication should be noted here. This syndrome is characterized by systematic deactivation of immune response as a means of restoring homeostasis in severe infection disease or injury. ${ }^{1}$ Unfortunately, this possibility could not be verified by pathological examination, as the family of the patient did not give consent.

In cases of scrotal swelling of infectious genesis, differential diagnosis should include Fournier's gangrene, a type of necrotizing fasciitis affecting the external genitalia and perineum. ${ }^{6}$ Risk factors for Fournier's gangrene include diabetes mellitus, alcohol abuse, obesity, and immunosuppression; these overlap somewhat with the risk factors for acute pancreatitis.

In conclusion, although a scrotal abscess is a rare complication of acute necrotizing pancreatitis, it should be considered in unclear cases of acute scrotum in adults, especially those with a history of biliary colic or alcohol abuse. Computerized tomography is essential in reaching a correct diagnosis in unclear cases of scrotal swelling, and it also provides information about the extent of inflammation. In this case, it also gave exact information about the source of infection and the descent of retroperitoneal collections to the scrotum.

Acknowledgment. We thank Maja Pandza, MD, for reviewing radiology materials used in this paper for clarity and correctness. We would like to thank Scribendi inc. for English language editing.

\section{References}

1. Manohar M, Verma AK, Venkateshaiah SU, Sanders NL, Mishra A. Pathogenic mechanisms of pancreatitis. World J Gastrointest Pharmacol Ther 2017; 8: 10-25.

2. Foster BR, Jensen KK, Bakis G, Shaaban AM, Coakley FV. Revised atlanta classification for acute pancreatitis: A pictorial essay. Radio Graphics 2016; 36: 675-687.

3. Wilde C, Abdelrazeq A. Acute scrotal pain as sole presentation of acute pancreatities. Int J Surg Case Rep 2014; 6C: 71-72.

4. Malayala SV, Sa'ati A, Raza A. Pancreatic Hydrocele: A Case Report and Review of Literature. Pancreas 2015; 44: 1164-1165.

5. Moens L, Yengue Yengue P, Assenmacher C. Intrascrotal collection in an acute pancreatitis: A case report and review of the literature. Case Rep Urol 2016; 2016: 7534781.

6. Singh A, Ahmed K, Aydin A, Khan MS, Dasgupta P. Fournier's gangrene. A clinical review. Arch Ital Urol Androl 2016; 88: $157-164$. 